Jarosław Struniawski

\title{
1. SELECTED LEGAL ISSUES IN CBRN-E
}

International terrorism as a social phenomenon is one of the most serious contemporary threats to national and global security. The targets of terrorist and extremist groups might include industrial plants and research institutes (located in cities), that use dangerous substances. A terrorist attack on such facilities might lead to an industrial failure, with effects going beyond their grounds and biohazards causing epidemics.

The essence of terrorism is lawlessness and illegal use of violence in attacks using combat assets, with the aim of enforcing an activity, or intimidating a given community or government in order to achieve political, social, religious or personal goals. In order to maximise the number of victims, terrorists might also use unconventional weapons: weapons of mass destruction (WMDs). In the literature, this is referred to as 'superterrorism'.

Terrorists can obtain weapons of mass destruction and the technology for their production thanks to, for example, funds received from domestic or foreign states, e.g. Iran, North Korea, and Syria. What has also substantially contributed to this is the lack of any control over the weapons of mass destruction stockpiled in the area of the former USSR. In other countries, potential material suppliers include all kinds of chemical plants, biological laboratories, RTG facilities and radioactive waste disposal sites, while the Internet offers unrestricted access to information about the production of such weapons.

Reasons for attempts to use weapons of this kind by terrorist groups include:

- The intention to kill as many people as possible in a terrorist attack;

- The intention to escalate violence through the use of fear, in order to create panic and enhance the psychological effects;

- The desire to gain a clear advantage before negotiations with state governments - political blackmail;

- Ensuring terrorists' anonymity: attack can remain undiscovered for a long time, allowing the terrorists to flee the area, and optionally spread the substances over a larger area;

- Causing economic and social damage.

Weapons of mass destruction (WMDs) were originally classified in the 1950s, during the Cold War, as $\mathrm{ABC}$ weapons (Atomic, Biological and Chemical). Today, the modern American acronym NBCR is used: Nuclear, Biological, Chemical and Radiological. These all refer to modern munitions that are lethal or non-lethal to 
living organisms and, to some extent, inorganic matter, and act on a large scale, meaning large areas, large numbers, huge striking power with terrifying effects, leading to irreversible changes to the environment. Their agents can be far more effective than conventional weapons, and it is impossible to determine their harmful effects over time.

Mass killing agents released as a result of terrorist attacks might be dangerous to the health and life of people in contaminated or infected areas. It is very difficult to counteract the effects of such incidents and secure all of their potential sources - the greatest allies of terrorists are incompetent authorities, poorly organised rescue services, panic, and low levels of education about such incidents.

\subsection{Nuclear Weapon (Laws Covering Nuclear Weapons)}

After the Second World War, various other countries (following the United States) sought to obtain nuclear weapons. The atomic countries were joined by the Soviet Union, the United Kingdom, France, and China. As a result of this arms race, the world potentially faced global nuclear war. However, strong awareness of the threat of extermination of human civilisation among the decision-makers of the two largest powers, led to the taking of preventive actions. A significant role in the limiting of the nuclear proliferation and in the reduction of nuclear arsenals was played by the United Nations. Under the auspices of the UN, different working groups, committees and organisations prepared and ratified different treaties on nuclear weapons. The most important of these include:

- The Antarctic Treaty of August 4 1963, which forbade the military use of Antarctica, including the storing or testing of nuclear weapons;

- Partial Nuclear Test Ban Treaty of 5 August 1963, which forbade nuclear tests over ground, underwater and in outer space, but did not forbid underground nuclear tests;

- The Treaty on Principles Governing the Activities of States in the Exploration and Use of Outer Space, including the Moon and Other Celestial Bodies of 7 January 1967, which forbade placement of nuclear weapons in outer space;

- The Treaty on the Prohibition of Nuclear Weapons in Latin America and the Caribbean of 14 February 1967, which forbade the countries of Latin America and the Caribbean any work on the development of nuclear weapons;

- Nuclear Non-Proliferation Treaty (NPT) of 4 August 1963, which forbade the proliferation of nuclear weapons and technologies and conducting any further work in this respect;

- The Treaty on the Prohibition of the Emplacement of Nuclear Weapons and Other Weapons of Mass Destruction on the Sea-Bed and the Ocean Floor and in the Subsoil thereof of 11 February 1971; 
- Strategic Arms Limitation Talks I (SALT I) of 26 May 1972, which was the first treaty on the limitation of strategic armaments. It determined the limits for armaments of both superpowers, however, it did not mention limitation of existing arsenals. Signatories: the United States and the Soviet Union;

- The Treaty on the Limitation of Underground Nuclear Weapon Tests of 18 May 1974, which limited underground nuclear tests to a yield of 150 kilotons. Signatories: the United States and the Soviet Union;

- Strategic Arms Limitation Talks II (SALT II) of 18 June 1979, which was the second treaty on the limitation of strategic armaments. Implementation of the treaty's provisions made it necessary to withdraw certain types of warheads. Signatories were the United States, the Soviet Union and the United Kingdom;

- The South Pacific Nuclear Free Zone Treaty of 6 August 1985, which forbade testing, developing or obtaining nuclear weapons by countries from the South Pacific region;

- The Intermediate-Range Nuclear Forces Treaty of 8 December 1987, which banned the possession of short- and intermediate-range missiles (500$5,500 \mathrm{~km}$ ). All such missiles were eliminated (including the American Pershing missile and the Soviet SS-20 and SS-23);

- Strategic Arms Reduction Talks I (START I) of 5 December 1994, which was the first treaty on the reduction of strategic arsenals. It introduced a limitation on the number of strategic warheads of about $30 \%$ of then-current stocks. The signatories were the United States and the Soviet Union. However, on account of its dissolution in 1991, the protocol was signed by Russia, Belarus, Kazakhstan and Ukraine;

- Strategic Arms Reduction Talks II (START II), which was the second treaty on the reduction of strategic arsenals and constituted an entire package of documents. Ratified by the United States Senate in 1996, but not ratified by the Russian State Duma. It introduced further limitations on the number of nuclear warheads (to 3,000-3,5000) of both signatories. Pursuant to the Treaty, the use of multi-head missiles (MIR V) in intercontinental ballistic missiles (ICBMs) was also banned;

- Comprehensive Test Ban Treaty (CTBT) of 10 September 1996, which banned the conduct of nuclear tests by all countries owning nuclear weapons;

- Strategic Offensive Reductions Treaty (SORT) of 24 May 2002 (it came into force on 1 June 2003), which concerned the reduction of strategic offensive possibilities. The Treaty introduced the limitation of the strategic arsenals of its signatories to $1,700-2,200$ operationally deployed warheads each;

- Strategic Arms Reduction Treaty (START) of 8 April 2010 (it came into force on 5 February 2011), on the means of further reduction and limitation of strategic offensive forces (also referred to as START-3 or New START). This Treaty replaced the provisions of SORT and reduced the number of strategic nuclear missile launchers by half (including intercontinental ballistic missile 
launchers, submarines and strategic air forces). The treaty did not limit the number of liquidated missiles.

The fundamental international treaty forbidding the proliferation of nuclear weapons is the Nuclear Non-Proliferation Treaty. It was signed on 1 July 1968. Until 2008, its signatories included 189 countries. Only three countries refused to ratify it: Israel, India and Pakistan, while North Korea signed the Treaty in 1985 but withdrew from it in 2003. The Treaty was concluded for 25 years, and with a decision of its signatories in May 1995, was extended indefinitely. The Treaty was signed by Poland on 1 July 1968 and ratified on 3 May 1969. According to Polish law, it came into force on 5 May 1970.

The Treaty obliges nuclear countries not to provide anyone, directly or indirectly, with nuclear weapons or other nuclear explosive devices or control over such weapons or such explosive devices, and not to assist, encourage, or induce any of the non-nuclear countries to produce or otherwise acquire such weapons or control over such weapons or explosive devices. Furthermore, it emphasises the principle of making available the benefits and scientific information connected with the use of atomic energy for peaceful purposes. Nuclear countries were also obliged to make efforts to prevent the outbreak of nuclear war. Non-nuclear countries were obliged not to accept from anyone, directly or indirectly, nuclear weapons or other nuclear explosive devices or control over such weapons or such explosive devices, and not to produce or otherwise acquire such weapons, and not to seek or accept any help in their production. But the countries that did not sign the treaty have not been excluded from international work in the nuclear field. In certain cases, their situation is more favourable than with the parties to the treaty, as they are not obliged to subject themselves to detailed international inspections.

Disarmament efforts by international organisations and individual states have not stopped nuclear testing. During the Vietnam War and the Cold War, work on a treaty that would regulate the ultimate cessation of nuclear testing was abandoned.

\subsection{Chemical Weapons}

The first milestone in the codification of the law of war is considered to be the negotiation of the 11 Hague Conventions, which combined the respect for law with the customs of war on land. The $2^{\text {nd }}$ Convention, dated 29 July 1899 , and the $4^{\text {th }}$ Convention, dated 18 October 1907, banned in particular the use of poisons or poisoned arms, bullets and materials that might cause superfluous injuries.

Other diplomatic attempts to limit the use of chemical weapons during war led to the signing of the Geneva Protocol in 1925 for the Prohibition of the Use in War of Asphyxiating, Poisonous or other Gases, and of Bacteriological Methods of 
Warfare, and the Convention on the Prohibition of the Development, Production and Stockpiling of Bacteriological (Biological) and Toxin Weapons and on their Destruction in 1972. However, these documents did not specify any ways in which it could be verified as to whether they are followed. In consequence, many countries, despite having ratified the conventions, more or less openly worked on chemical weapons. Thus, creation of a new treaty was proposed that would provide for methods of controlling the spread, stockpiling and destruction of chemical weapons.

On 13 January 1993, one of the most significant documents of international law, the Convention on the Prohibition of the Development, Production, Stockpiling and Use of Chemical Weapons and on their Destruction - a.k.a. The Chemical Weapons Convention (CWC), was signed. The Convention has been in force since 29 April 1993 and has been signed by 127 countries.

The CWC is the first treaty in history that assumes complete elimination of the proliferation and use of chemical weapons, which is supposed to be achieved by destroying all stockpiled chemical weapons and by completely stopping production. The Convention obliges its signatories to provide information about chemical weapons they possess and to destroy them, and to provide information about their chemical industry.

The general obligations of the CWC's parties can be found in Article 1 of the Convention, which reads as follows:

1. Each State Party to this Convention undertakes to never, under any circumstances:

- Develop, produce, otherwise acquire, stockpile or retain chemical weapons, or transfer, directly or indirectly, chemical weapons to anyone;

- Use chemical weapons;

- Engage in any military preparations to use chemical weapons;

- Assist, encourage or induce, in any way, anyone to engage in any activity prohibited to a State Party under this Convention.

2. Each State Party undertakes to destroy chemical weapons it owns or possesses, or that are located in any place under its jurisdiction or control, in accordance with the provisions of this Convention.

3. Each State Party undertakes to destroy all chemical weapons it has abandoned on the territory of another State Party, in accordance with the provisions of this Convention.

4. Each State Party undertakes to destroy any chemical weapons production facilities it owns or possesses, that are located in any place under its jurisdiction or control, in accordance with the provisions of this Convention.

5. Each State Party undertakes not to use riot control agents as a method of warfare.

Since 1997, the executive body of the Convention has been the Organisation for the Prohibition of Chemical Weapons - the OPCW, which is based in The 
Hague. The Organisation supervises international adherence to the treaty, and is responsible for the implementation of international regulatory provisions and the elimination of global stocks of chemical weapons. A hundred and ninety countries are OPCW members.

Despite international conventions, there is a real danger of countries that have not signed the Convention using chemical weapons, and of their use by terrorist groups.

\subsection{Biological Weapons}

The role of the law is to support positive and to limit negative aspects of the development of new technologies, minimising threats and maximising their potential benefits. Every effort should be made to ensure that progress is not connected with increasing danger, but is used to improve the people's standard of living. Additionally, modern biotechnology shows enormous potential for improving people's well-being as long as it is developed using proper security measures with regard for the environment and people's health. Considering this, one has to highlight the necessity to make constant efforts to create such provisions that make it possible to fully exploit the potential of biotechnology, while at the same time ensuring protection against potential threats that arise out of its development.

Scientific research into the improvement of medical treatment methods and the prevention of infectious diseases is fully justified. However, the results might also be used for the wrong purposes. Some states or terrorist groups, under the pretext of undertaking scientific activity (to create vaccines against infectious diseases), use the developments of biological sciences, including microbiology and genetic engineering, in an attempt to create weapons of mass destruction. The possibility of obtaining and using highly infectious micro-organisms or their toxins for bioterrorist purposes makes it necessary to exercise strict control over such research - not only over materials that could be used as weapons, but also over the possibility of such agents being obtained by non-governmental groups. This security should ensure the prevention of the production and stockpiling of biological weapons, and its effectiveness should be guaranteed by signed international agreements forbidding the use of biological weapons.

The first attempt to develop regulations on biological weapons was the Geneva Protocol, signed on 17 June 1925, which banned the use of biological and chemical methods of warfare. The guarantee for the provisions of the treaty was the obligation of such countries as the United Kingdom, France, China and the United States to retaliate against countries that break the established rules by deciding to use biological or chemical weapons. The treaty was signed by 108 countries, and Poland ratified it on 4 February 1929. 
The Geneva Protocol bans any use of bacteriological methods of warfare during armed conflict. Today, this ban is a commonly-binding standard of international law, which has been confirmed by numerous resolutions of the UN General Assembly. However, while it covers the use of bacteriological weapons during war, it does not cover activities preceding preparations for war, meaning research on biological weapons, their production and stockpiling. As such, it was necessary to sign an agreement that would also cover peacetime. Consequently, on 10 April 1972, the Convention on the Prohibition of the Development, Production and Stockpiling of Bacteriological (Biological) and Toxin Weapons and on their Destruction (a.k.a. the Biological Weapons Convention - BWC) was signed, and it was ratified on 26 March 1975 . The most important obligations of the state parties to the BWC are as follows:

- Article I - Each State Party to this Convention undertakes never under any circumstances to develop, produce, stockpile or otherwise acquire or retain: microbial or other biological agents, or toxins whatever their origin or method of production, of types and in quantities that have no justification for prophylactic, protective or other peaceful purposes; weapons, equipment or means of delivery designed to use such agents or toxins for hostile purposes or in armed conflict.

- Article II - Each State Party to this Convention undertakes to destroy, or to divert to peaceful purposes, all agents, toxins, weapons, equipment and means of delivery.

- Article III - Each State Party to this Convention undertakes not to transfer to any recipient whatsoever, directly or indirectly, and not in any way to assist, encourage, or induce any State, group of States or international organisations to manufacture or otherwise acquire any agents, toxins, weapons, equipment or means of delivery.

- Article IV - Each State Party to this Convention shall take any necessary measures to enforce the BWC's provisions.

- Article V - The State Parties to this Convention undertake to consult one another and to work together in solving any problems that may arise in relation to the objective of, or in the application of the provisions of, the Convention.

- Article VI - Any State Party to this Convention that finds that any other State Party is acting in breach of its obligations deriving from the provisions of the Convention may lodge a complaint with the Security Council of the United Nations.

- Article VII - Each State Party to this Convention undertakes to support or provide assistance, in accordance with the United Nations Charter, to any Party to the Convention that so requests it, if the Security Council decides that such Party has been exposed to danger as a result of violation of the Convention.

- Article X - The State Parties to this Convention undertake to implement the above provisions in a manner that encourages peaceful use of biological sciences and technology. 
The provisions of the Convention also cover weapons that might be produced using genetic engineering and other developments of modern biotechnology. Consequently, the notion of 'black biotechnology' was introduced. This refers to the use of biotechnology in the context of such threats as biological war and bioterrorism to harm people, animals and plants. Activities were also undertaken based on other international agreements, to control black biotechnology and compliance with the ban on the use of biological weapons. One example of this is the so-called Australian Group (AG), which involves the cooperation of 41 countries (including Poland), and the European Commission. The aim of the Group is to minimise the threat of the spread of biological and chemical weapons through coordination of its members' export policies. This is achieved thanks to Common Control Lists - lists of goods and technologies that, because they can be used in the production of biological or chemical weapons, are subjected to special export control. The biological agents on the Australian Group's lists also include genetically modified organisms (GMOs). Moreover, the state parties to the Biological Weapons Convention undertake to submit to the UN annual reports on the outbreak of epidemics, on facilities conducting research on the methods of protection against biological weapons, scientific conferences organised in specific facilities, and the exchange of information and scientists.

The Convention was the first multilateral treaty that effectively banned developing, producing, acquiring, transferring, stockpiling, and using biological and toxin weapons. However, the BWC does not forbid conduct of research into, and improvement of, agents that ensure protection against such weapons, as such research is necessary to produce new drugs and protective agents. Thus, it makes it possible to conduct secret activities and makes it difficult to verify the compliance with its provisions.

Another international agreement - and the first to be directly connected and devoted in whole to the protection of the environment and human health against the potential dangers of modern biotechnology - is the Cartagena Protocol on Biosafety (CPB), which was drawn up on 29 January 2000 in Montreal. The Cartagena Protocol covers modified organisms being the products of modern biotechnology. These include organisms the characteristics of which pose a threat to the health of people, animals or plants, and which could be used as biological weapons.

There are also other initiatives aimed at preventing the use of, and controlling the production of, biological agents that could be used as biological weapons. However, these are mostly informal. 


\section{References}

Adamski J., Nowe technologie w stużbie terrorystów, Warszawa 2007.

Aleksander Y., Hoenig M. (ed.), Superteroryzm biologiczny, chemiczny i nuklearny, Warszawa 2001.

Aleksandrowicz T., Terroryzm międzynarodowy, Warszawa 2008.

Alibek K., Biohazard, Warszawa 2000.

Bartel Z., Broń chemiczna (wojna gazowa), Bydgoszcz-Warszawa 1924.

Bąk T. (ed.), Oblicza Terroryzmu, Kraków 2011.

Białek T., Terroryzm. Manipulacja strachem, Warszawa 2005.

Bielicka H. (ed.), Raport sekretarza generalnego ONZ o broni chemicznej i bakteriologicznej (biologicznej) oraz o skutkach ich ewentualnego użycia, Warszawa 1969.

Bogdalski P., Nowakowski Z., Płusa T., Rajchel J., Rajchel K. (ed.), Wspótczesne zagrożenia bioterrorystyczne i cyberterrorystyczne a bezpieczeństwo narodowe Polski, Warszawa 2013.

Bogdalski P., Nowakowski Z., Rajchel K., Ocena poziomu zagrożenia terroryzmem i organizacji systemu antyterrorystycznego w Polsce, Szczytno 2012.

Bolechów B., Terroryzm, aktorzy, statyści, widownie, Warszawa 2010.

Bolechów B., Terroryzm w świecie podwubiegunowym, Torun 2002.

Breitkopf B., Marciniak M., Worwa Z., Przysposobienie obronne, Warszawa 2002.

Broń jądrowa. Podręcznik, Warszawa 1964.

Bukowski St., Terroryzm europejski. Geneza i wspótczesne zagrożenia, Słupsk 2010.

Chomiczewski K., Kocik J., Szkoda M.T., Bioterroryzm. Zasady postępowania lekarskiego, Warszawa 2002.

Ciupiński A., Zając M., Wybrany problemy walki z terroryzmem międzynarodowym, Warszawa 2003.

Coleman K., A History of Chemical Warfare, New York 2005.

Danzig R., Catastrophic bioterrorism - what is to be done?, Washington 2003.

Durys P., Broń chemiczna. Działania na rzecz zakazu i eliminacji, Warszawa 2009.

El Baradei M., Gra pozorów. Arsenat nuklearny a dyplomacja, Wrocław 2011.

Fehler W. (ed.), Wspótczesne bezpieczeństwo, Toruń 2003.

Gawliczek P., Pawłowski J., Zagrożenia asymetryczne, Warszawa 2003.

Gąsiorek K., Kitler W. (ed.), Wojskowe wsparcie władz cywilnych i społeczeństwa, Warszawa 2005.

Grabowski D., Rabiej S., Ochrona przed skażeniami w obronie cywilnej. Część I, Warszawa 1989.

Grabowski D., Rabiej S., Ochrona przed skażeniami w obronie cywilnej. Część II, Warszawa 1989.

Grudziński P., Teologia bomby. Narodziny systemu nuklearnego odstraszania 1939-1953, t. I, Bomba atomowa, Warszawa 1988.

Hołyst B., Terroryzm, t. 1-2, Warszawa 2010.

Hołyst B., Jaroszyński K., Letkiewicz A., Wojna z terroryzmem w XXI wieku, Szczytno 2009.

Jałoszyński K., Organy administracji rządowej wobec zagrożeń terrorystycznych. Siły Zbrojne wobec terroryzmu, Bielsko-Biała 2011. 
Jałoszyński K., Współczesny wymiar antyterroryzmu, Warszawa 2008.

Jałoszyński K., Wspótczesne zagrożenia terroryzmem, Szczytno 2013.

Jałoszyński K., Letkiewicz A., Edukacja antyterrorystyczna, Szczytno 2010.

Jałoszyński K., Wiśniewski B., Terroryzm - Diagnoza, zadania administracji publicznej w przeciwdziałaniu zjawisku, Bielsko-Biała 2007.

Jałoszyński K., Zalewski S., Organy administracji rządowej wobec zagrożeń terrorystycznych. Służby specjalne wobec terroryzmu, Bielsko-Biała 2009.

Janik A., Charakterystyka skażeń promieniotwórczych i chemicznych oraz niektóre zasady ochrony ludności cywilnej przed nimi, Warszawa 1973.

Jasienica P., Polska Piastów, Warszawa 1997.

Jeleń K., Rau Z. (ed.), Energetyka jądrowa w Polsce, Warszawa 2012.

Kalinowski R., Obrona cywilna w Polsce, Siedlce 2011.

Kasperek T. (ed.), Broń chemiczna zatopiona w morzu battyckim, Gdynia 1998.

Katalog broni masowego rażenia i środków ochrony państw NATO, Warszawa 1981.

Kepka P., Bioterroryzm. Polska wobec użycia broni biologicznej, Warszawa 2009.

Kitler W. (ed.), Planowanie cywilne w zarzadzaniu kryzysowym, Warszawa 2011.

Konopski L., Historia Broni chemicznej, Warszawa 2009.

Kowalczyk K., Wróblewski W., Oblicza wspótczesnego terroryzmu, Torun 2006.

Krauze M., Współczesna broń chemiczna, Warszawa 1985.

Krauze M., Nowak I., Broń chemiczna, Warszawa 1984.

Kubowski J., Broń jądrowa. Fizyka, budowa, działanie, skutki, Warszawa 2003.

Kurkiewicz A. (ed.), Zarządzanie kryzysowe w samorzadzie, Warszawa 2008.

Lediel K., Piasecka P., Jak przetrwać w dobie zagrożeń terrorystycznych, Warszawa 2008.

Lenbein K., Skalnik Ch., Smolek I., Bioterroryzm, Warszawa 2003.

Letkiewicz A., Nowakowski Z., Rajchel J. (ed.), Wspólna polityka bezpieczeństwa i obronności. Implikacja dla Polski, Warszawa 2011.

Liedel K. (ed.), Terroryzm anatomia zjawiska, Warszawa 2006.

Liedel K., Zarzadzanie $w$ walce $z$ terroryzmem, Warszawa $2010 \mathrm{r}$.

Liedel K., Piasecka P., Jak przetrwać w dobie zagrożeń terrorystycznych, Warszawa 2007.

Machowski A., Zagrożenia bioterroryzmem, Mysłowice 2008.

Michailiuk B., Broń biologiczna, Warszawa 2008.

Pawłowski J., Broń masowego rażenia orężem terroryzmu, Warszawa 2004.

Pawłowski J., Terroryzm we współczesnym świecie, Warszawa 2001.

Piątek Z., Zdrojewski A. (ed.), Bioterroryzm, Warszawa 2013.

Michailiuk B., Broń biologiczna, Warszawa 1986.

Pilch R.F., Zilinskas R.A., Encyclopaedia of Bioterrorism Defense, Wiley 2005.

Pióro T., Broń jądrowa. Geneza - dziatanie - skutki, Warszawa 1971.

Płusa T., Jahnz-Różyk K., Broń biologiczna - zagrożenie i przeciwdziałanie, Warszawa 2002.

Prusakowski M., Bioterror. Jak nie dać się zabić?, Łódź 2001.

Rabiej S. (ed.), Ochrona przed skażeniami w obronie cywilnej, t. I i II, Warszawa 1981.

Rhodes R., Jak powstała bomba atomowa, Warszawa 2000.

Rojszczak M., Broń jądrowa. Boży gniew, 2001 edition.

Rothschild J.H., Broń jutra chemiczna i biologiczna, Warszawa 1970.

Sieńko J., Szlachcic B., Bezpieczeństwo wewnętrzne państwa $w$ dobie walki z terroryzmem, Warszawa 2005. 
Szafrański J. (ed.), Wspótczesne zagrożenia terroryzmem oraz metody ich zwalczania, Szczytno 2007.

Szafrański J., Kosiński J., Wspótczesne zagrożenia terrorystyczne oraz metody ich zwalczania, Szczytno 2008.

Szweykowska A., Szweykowski J. (ed.), Stownik botaniczny, Warszawa 1993.

Śladkowski S., Ocena potencjalnych zagrożeń bronią masowego rażenia i skutków jej użycia, Warszawa 2004.

Śladkowski S., Solarz J., Malicki E., Michailiuk B., Obrona przed bronią masowego rażenia, Warszawa 2007.

Treder M., Pandemie. Zagrożenie XXI wieku, Warszawa 2012.

Urban A. (ed.), Zarządzanie kryzysowe wyzwaniem dla edukacji, Szczytno 2007.

Witkiewicz Z. (ed.), 1000 stów o chemii i broni chemicznej, Warszawa 1987.

Wojciechowski S., Terroryzm na początku XXI wieku, Kraków 2011.

Wolanin J., Zarys teorii bezpieczeństwa obywateli. Ochrona ludności na czas pokoju, Warszawa 2005.

Yonah A., Milton H., Superterroryzm, Warszawa 2001.

Zieliński K., Bezpieczeństwo obywateli podczas kryzysów niemilitarnych oraz reagowanie $w$ razie katastrof $i$ klessk żywiołowych, Warszawa 2004.

Zieliński K., Brocki M., Janiak M., Wiśniewski A., Patologia obrażeń i schorzeń wywołanych współczesna bronia $w$ działaniach wojennych i terrorystycznych, Warszawa 2010.

Zięba R., Bezpieczeństwo międzynarodowe po zimnej wojnie, Warszawa 2008.

Zubrzycki W. (ed.), Przeciwdziałanie zagrożeniom terrorystycznym w Polsce, Warszawa 2011.

Żuber M. (ed.), Katastrofy naturalne i cywilizacyjne. Terroryzm wspótczesny. Aspekty polityczne, społeczne i ekonomiczne, Wrocław 2006.

Act on Biocidal Products of 13 September 2002, Journal of Laws of 2002 No. 175, item 1433.

Act on the Branches of Government Administration of 4 September 1997, Journal of Laws of 2003 No. 159, item 1548.

Act on Commune Self-Government of 8 March 1990, Journal of Laws of 2001 No. 142, item 1591.

Act on Crisis Management of 26 April 2007, Journal of Laws No. 89, item 590, as amended.

Act on District Self-Government of 5 June 1998, Journal of Laws of 2001 No. 142, item 1592.

Act on General Defence Obligation of the Republic of Poland of 21 November 1967, Journal of Laws of 2012, item 461, as amended.

Act on the Government Administration in the Province of 5 June 1998, Journal of Laws of 2001 No. 80, item 872 .

Act on the Prevention and Fighting Against Infectious Diseases in People of 5 December 2008, Journal of Laws of 2008 No. 234, item 1570.

Act on the Province Governor and the Government Administration in the Province of 23 January 2009, Journal of Laws of 2009 No. 31, item 206, as amended.

Act on Provincial Self-Government of 5 June 1998, Journal of Laws of 2001 No. 142, item 1590. 
Building Code Act of 7 July 1994, Journal of Laws of 1994 No. 89, item 414.

Constitution of the Republic of Poland, Journal of Laws of 1997 No. 78, item 483.

Environmental Protection Act of 27 April 2001, Journal of Laws of 2008 No. 25, item 150.

Guidelines of the Chief of the National Civil Defence of 17 October 2008 on the principles of evacuating people, animals and property in the case of a mass threat.

Guidelines of the Chief of the National Civil Defence of 21 April 2009 on the principles of organisation and the procedure for conducting training courses in population protection and civil defence.

Medical Rescue Act of 8 September 2006, Journal of Laws of 2006 No. 191, item 1410.

Narodowy Program Antyterrorystyczny Rzeczypospolitej Polskiej na lata 2012-2016.

Nuclear Law Act of 29 November 2000, Journal of Laws of 2001 No. 3, item 18.

Ordinance of the Council of Ministers of 28 September 1993 on the universal self-defence of the population, Journal of Laws No. 91, item 42.

Ordinance of the Council of Ministers of 28 September 1993 on civil defence, Journal of Laws of 1993 No. 93, item 429.

Ordinance of the Council of Ministers of 17 December 2002 on stations for early detection of radioactive contamination and units conducting measurements of radioactive contamination, Journal of Laws of 2002 No. 239, item 2030.

Ordinance of the Council of Ministers of 18 January 2005 on emergency procedures in the case of radiation incidents, Journal of Laws of 2005 No. 20, item 169.

Ordinance of the Council of Ministers of 7 January 2013 on the systems of detecting contaminations and reporting their detection, and on bodies competent with regard to these issues, Journal of Laws of 2013, item 96.

Ordinance of the Minister of the Environment of 30 December 2002 on serious failures that need to be reported to the Chief Environmental Protection Inspector, Journal of Laws of 2003 No. 5, item 58.

Police Act of 6 April 1990, Journal of Laws of 1990 No. 30, item 179.

State Fire Service Act of 24 August 1991, Journal of Laws of 1991 No. 88, item 400. State of Emergency Act of 18 April 2002, Journal of Laws of 2002 No. 62, item 558. Strategia Bezpieczeństwa Narodowego Rzeczypospolitej Polskiej, Warszawa 2014. 